\title{
Narayan's My Days: a Portrayal of the Relationship of Life with Letters
}

\author{
Subismita Lenka, Bhabani S. Baral \\ ${ }^{1,2}$ Asst. Professor Dept. Humanities \& Social Sciences Institute of Technical Education \& Research Siksha 'O' \\ Anusandhan University Jagamohan Nagar, Jagamara, Bhubaneswar-751030
}

R.K.Narayan's My Days, published in 1974 is an autobiography with a difference. Ordinarily an autobiography is considered a piece of realistic writing true to the nuances of an individual's life. On the contrary, at times, as in the case of V.S.Naipaul, a novel is attached the tag of "non-fiction writing". However, the truth of the matter is that every fiction has an element of non-fiction just as every non-fiction has an iota of fiction in it. It is worthwhile to mention here that just after the publication of Narayan's memoir, the American University, Washington D.C. chose the same for the English-speaking Union's Book Abroad Literary Award.

Narayan's autobiography, like his novels, is regional in that it conveys an intimate sense of a given place - in the novels, Malgudi; in My Days, Mysore - but it is not parochial or shuttered. The life in his memoir is that of Narayan's own class, the Indian middle class, where people are not too well-off to be unperturbed about money or brutalized by the total lack of it. And above it Narayan, appears like the hero of one of his novels - sensitive, ardent, modest and wry about himself, and with a hidden resolute will. In the memoir we see, as we do in the novels, first the context of the town and the skills and problems of various kinds of work which fascinate Narayan; within this the subtler circle of the family; Narayan himself, another Narayan hero. The author as a hero can be characterised as a balanced combination of inherited tradition with a positive individual talent. Narayan's novels are easily branded as "comedies of sadness", his autobiography, in the language of Krishna Pachegaonkar, "is both suffused with a pure and unaffected melancholy and also lighted with the glint of mockery of both self and others." (p.63)

After going through a few pages, of My Days a serious reader gets the impression that in many ways it is very similar to a Narayan novel. It certainly brings home to one how much of his fiction and not only the strikingly personal The English Teacher is firmly entrenched in the details of his own experience. R.K.Narayan admits in My Days,

The English Teacher is autobiographical in content, very little part of it being fiction. The English Teacher of the novel, Krishna, is a fictional character in the fictional city of Malgudi; but he calls his wife Susila, and the child is Leela instead of Hema. The toll that typhoid took and all the desolation that followed, with a child to look after, and the psychic adjustments, are based on my wife (Rajam) should to some extent give the reader a clue that the book may not be all fiction. (pp.150-1)

The book appeared six years after the death of the author's wife, in the year 1945. Hema, the little daughter made it possible for Narayan to recover from his wife's death. She tethered him to life. Like Rajam, Susila was from Coimbatore and both of them suffered from the same royal fever, typhoid. And in a month or two they died leaving their daughter and husband all alone. Within five years of marriage Narayan lost his wife and the astrologer who had found the horoscopes of the couple not matching was proved right. This tragic experience left a void in his life and he never married to fill it. His daughter wanted his caresses and affection. This pre-occupation of looking after a motherless child gradually moulded him and made him lead a sociable life. Hema's thought and responsibility never allowed Narayan to escape. The result is The English Teacher and the gift of voluminous other works of the author for the society.

Narayan's protagonist, Krishnan followed the author's footsteps in the novel The English Teacher. Even though he went for an arranged marriage and had to live a few years without his wife and daughter, his love for his wife is no less than Narayan. Like Narayan, his hero earned his livelihood from English literature, as he was a professor in English at Albert Mission College. He had to deal with Shakespeare, Carlyle, Milton and so on. As a professional, Krishnan was an able teacher and was loved by his students. The farewell speech of $\mathrm{Mr}$ Brown, the principal of Albert Mission College is an ample testimony to this. Krishnan was regular and punctual in his work even after his wife's death. Being an affectionate and responsible husband and father, he shared his time with both of them. He prepared the sick room, maintained the chart of Susila's temperature, pampered her to take medicine, and spent time with her. On the other hand, when he was freed from these responsibilities, he was back on his father's role. Read stories to his daughter, Leela; played with her; took her for outing. He also looked after her cleanliness, food, etc. By now Krishnan had started playing the role of both father and mother to his child. Same must be the situation for Narayan himself. And very soon he had to take 
care of all the requirements of Leela, as Susila collapsed one fine evening. This terrible experience left its indelible mark on Krishnan and like Narayan he decided not to marry again. Susila like Rajam died out of typhoid after she had spent a holiday at her parents' place at Coimbatore. After his wife's death Krishnan said, "I'm an imbecile, incapable of doing anything or answering any questions. I'm incapable of doing anything except what our priest orders me to do." (p.96) And the same man responded sensibly and intelligently to the problems that came on his way, only for his child. One finds the intensity of pain and agony in the writings of Narayan especially, in handling this episode. And can also visualise Rajam in place of Susila through the thoughts of the author. Like Hema, Leela also made his father come out of his mother's thoughts, and lead his life. Krishnan's life like Narayan's after his wife's tragic fate revolved around Leela.

The conversation between the father and child on trivial issues, the father's concern, and their affection for each other made the readers think it to be Narayan's real life experience. In her child-like innocence, Leela made her father answer her childish questions. Making Krishnan busy with her work forces the readers visualise Narayan in place of Krishnan. Narayan must have undergone similar pain and faced such situations in his real life. For instance, once Leela insisted upon being read the stories by his father in the odd hour. He makes plea of cleaning oneself before touching books, as Goddess Saraswathi, the Goddess of learning would be unhappy with them. To which she enquires, "Why should I be learned?" And her father adds, "You can read a lot of stories yourself without my help. Oh! What will you do then?" (p.103) The intensity of feeling, the accuracy of thought, compelled his critics to find an autobiographical element in it. Another incidence worth mentioning here is the lawyer episode. In Narayan's memoir it is mentioned that a lawyer in his street once peeped over his gate and said,

"Sorry, mister. I have also suffered the same fate. You must and will get over it." He had lost four wives in his matrimonial career and remarried each time, but at the moment was again a widower. (pp.153-4)

And in The English Teacher Narayan has used a perfect stranger, old woman, who by seeing the motherless child Leela peeps from the bus and comments,

A man must marry within fifteen days of losing his wife. Otherwise he will be ruined. I was the fourth wife to my husband and he always married within three weeks. All the fourteen children are happy. What is wrong? (p.99)

The original thought of the lawyer, the neighbour of the author is presented through the old lady in The English Teacher. Narayan wanted to reply to the lawyer in his real life and could not. So also did his character, Krishnan in the novel.

The protagonist, by profession an English teacher had the creative skill of writing poems and even wished to get them published. Narayan's trait of writing is also shared by Krishnan in The English Teacher. Like the author he also thought of writing a poem on the situation, of his wife, when the mercury in the thermometer was static at the highest level and was not falling. Kishnan sitting near his sick wife and seeing her talking in sleep, wrote,

The Great Kailas is one Mound of Ice

Where Shiva and Parvathi sport,

But so far it is not the fever which cools,

But Ice that melts. (p.86)

Krishnan follows the foot prints of his author to get rid of this dilemma. Narayan, as he did in his real life, makes his hero take the help of art by complete submission to it in this most difficult situation. And through the poem Krishnan could give vent to his sentiment and make himself prepared for the next tough situation. His agony and worry is distinctly visible in the poem, his love and concern too. Unlike Narayan he could not write a novel but has written a poem for her wife with utmost candidness.

The second part of The English Teacher also consists of autobiographical touch. Ragunath Rao (in Narayan's personal life) and the farmer (in his protagonist's life) helped in psychic communion with their respective wife. And the author's experience at Ragunath's place is being shared by Krishnan in the novel. The regular visit on Wednesdays, sitting fingers crossed to get some message from his wife, preserving the filled scripts of the psychic communion for life long and even self attempt of psychic communion are Narayan's life experience, represented through his hero.

Another novel of R.K.Narayan, The Bachelor of Arts (166 page creative production) is divided into four parts - education, infatuation, realisation and conjugal prosperity of Chandran. The protagonist Narayan, another Narayan hero, can co-relate his experiences with Chandran. The presence of autobiographical element in his writings makes him a hero in his memoir My Days. This is not the case with Narayan alone. The other novelists like Defoe, Richardson and James Joyce are in the game; they try to keep themselves away from their creativity but cannot betray their opinion. The choice of characters, situations, the thoughts and feelings are of the author. 
There is more of Narayan's personal influence in the second novel The Bachelor of Arts than in any other except The English Teacher, which happens to be the fourth in the series of creation. Chandran's experiences in Albert college; trying to stick to the exam preparation time-table, being part of non-academic matters, passing comments on teachers and principal at his naughty mood, playing pranks with friends, attending classes sincerely and obeying his teachers; seem to be based on the author's life experience in Maharaja's college, Mysore. The vivid description of these scenes forces his readers to deduce the conclusion that it is only Chandran who is playing the role of real Narayan in the novel. Ramu, his "inseparable friend", who keeps his company during and long after the college hours, smokes and watches late night movies is Ramachandra Rao, who finds a mention in his memoir My Days and jointly studied in the days of his final year examination. Perhaps, like the hero he also misses him long after their academic career. Chandran and Ramu, friend and neighbour of the protagonist started the day with their journey to the college, attended the lectures, returned home only to freshen up for the night show cinema. Narayan writes, "Chandran was none of your business-like automatons who go to a cinema, sit there, and return home. It was an aesthetic experience to be approached with due preparation."(p.13) Both accompanied each other in chewing betel leaves and nut; smoking cigarette all the time they were together and icing it with the midnight coffee. Chandran adds, "Ramu's company was most important to him. It was his presence that gave a sense of completion to things."(p.13) And same was Ramachandra for Narayan.

Chandran of The Bachelor of Arts falling headlong in love with Malathi, who came to the river bank of Sarayu with her younger sister almost daily, reminds one of Narayan of 1933. It reminds of similar incidents Narayan went through when he had gone to Coimbatore escorting his elder sister and lived in her place. Both the love stories flourished near the water source, one playing with her sister near the river bank and other drawing water from the tap. Like Chandran, his author says in the memoir, "One day, I saw a girl drawing water from the street-tap and immediately fell in love with her.'(p.117) And in the novel explaining both the lovers' condition he writes, "No one can explain the attraction between two human beings. It happens."(p.54) The horoscopes in both the lovers' life i.e., Chandran and Narayan created difficulties in the union with their beloveds. Ganapathi Sastrigal (in the novel), the match-maker's idea on horoscope "to know whether two persons brought together will have health, happiness, harmony, and long life" (p.78) was also the thought of both the parents (bride and groom) within and outside the novel. Narayan succeeded in making the stars favourable (for the time being) and could convince the girl's father to agree to the marriage. Chandran and his father did their best with the astrologer, Srouthigal to make the two horoscopes "well matched". But D.W.Krishna Iyer, father of the girl, who had little knowledge of astrology had his doubts. He says,

Since I have great faith in horoscopy, and since I have known from experience that the marriage of couples ill-matched in the stars often leads to misfortune and even tragedy, I have to seek a bridegroom elsewhere.(p.86)

These words made Chandran, writes Sundaram, fall into "the deepest depths of despair". This incident led Chandran to leave Malgudi and seek solace in the ochre robes. But in case of Narayan the love-story ended with the bondage of wed-lock.

Another character of The Bachelor of Arts, Kailas the eccentric hotel mate of Chandran at Madras, who considered beer as lacking in alcoholic content, offered it to Chandran, the non-alcohol consumer. He could even steadily drink gin after whisky and whisky followed by gin from five to eight-thirty in the evening. The author imagining one of his younger uncle's drunken bouts mentioned in his autobiography that Kailas is modelled after him, as he was equally fond of bottles. Then he became a fake tiger who snarled and stalked in the hotel corridor behind every passerby until sleep took over. Kailas raised a similar kind of situation for the protagonist in the bar, on the street and near his temporary destination. Even Seenu, Chandran's younger brother is not a fictitious character rather one of Narayan's brother, who was of the same name and characteristics. In My Days Narayan writes, "Seenu, one year junior in our class, always obliging, would willingly undertake ....."(p.79) any responsibility assigned to him.

While discussing Narayan's life, none can forget Narayan's creative career, which is represented by Mohan, friend of Chandran in The Bachelor of Arts. Mohan, the newspaper reporter of The Daily Messenger in the novel, and the author, were into the same profession for the Justice and Indian Thought of Madras. Both the reporters dealt with cases in the court, traffic accidents, suicides and murders, and were busy in posting them. Sundaram writes,

When Chandran gets the agency for The Daily Messenger and plans his four-pronged attack on the public to push up its sales -- Information, Illumination; Appeal and Force -- it is difficult not to conclude that some such process must have been set in motion by Narayan himself when he embarked on his journalistic venture Indian Thought.(p.27)

One such occurrence is when Chandran returns from his exile and looks for his "inseparable friend" Ramu, but never received any satisfactory answer. Then he reminiscences the moment they shared together and comments how they studied for four years, developed compatibility, made friends, arranged functions. All these 
are saved in a group photograph, which after a few years was sent to the store room. In a passage in My Days Narayan has dealt with a similar theme i.e., school photograph. Looking at a school photograph consisting of teachers and students, Narayan can name only two. For eight long years he like his hero reminiscences, "reading, playing and suffering our teachers together...... where are my fellow Olympians at this moment?"(p.46)

In a way Narayan's first novel, Swami and Friends which deals with the hero's growth into maturity through a number of adolescent audience, is an autobiographical novel. A section of My Days is strongly reminiscent of these events of the Narayan novel. In those days a child being brought up elsewhere than in the care of one's parents was something common and Narayan too was sent to his granny in Madras so that the young mother can care for the other children. The boy Narayan's liking for domestic animals: the peacock, the monkey, the green parrot and the little hairy puppy is something which can hardly be ignored. Walking in the streets of Madras hand in hand with his uncle, he received enormous materials which were nutrition for his imagination and education for his feelings. Both in My Days and Swami and Friends Narayan's life in Madras and his nostalgia for the school days are all too common. Going through the highly readable autobiography of Mr Narayan one gets a scent of his attention, his allergy for abstract arithmetic, his irritability with intrusive adults and his desperate attempt to manage the unyielding angularities of the adult world. One more thing that strikes a discerning reader is Narayan's portrayal of his father as a stern headmaster, not very different from the headmaster of the Swami and Friends.

In Mr Sampath: The Painter of Malgudi one can observe the similarity of Srinivas' professional career with Narayan. As we know Narayan himself edited a journal like Srinivas. Even Narayan's Indian Thought was less successful and more baffling in its purpose than The Banner of Mr.Sampath. Narayan writes in My Days, 'Mr. Sampath, who was my printer (and who became a character in one novel and two film stories), had said bluntly, 'I'll do the printing side but you must provide the paper...'(p.173) And Sampath in the novel is modelled on real life one, who had versatile talents. Beside printing, both had knack for theatre. The author's experience with the zany Indian film industry when they introduced all sorts of lunatic energies on producing a commercial version of his favourite novel The Guide, is not different from that of Srinivas (The Burning of Kama). The novelist mentions in his memoir that the multi-faceted Sampath of real life, i.e. Narayan, also became a busy film personality without neglecting his press work. Srinivas represents the author's adventures in running Indian Thought and Sampath follows his example with his experience of the film industry. This has much similarity with V.S.Naipaul who is believed to use autobiographical elements in his works.

There is also reference to Narayan's life falling "firmly into a professional pattern: books, agents, contracts........"(p.209) and it has found its place in another novel of his i.e., The Guide. Raju, the protagonist had to pass through similar situations like his author while he was a career-guide to Rosie. Narayan's numerous letters to known and unknown people alike, his travels for days together, and above it his enjoyment of the situation rather than complaints also has a mention in this highly rated novel. In 1956 Mysore faced a severe drought and it dried up all the rivers and tanks; revealed an ancient submerged temple, dehydrated crocodiles. Narayan writes in his autobiography, "At this time I had been thinking of a subject for a novel: a novel about someone suffering enforced sainthood. A recent situation in Mysore offered a setting for such a story."(p.188) And this became the theme for the novel. Apart from rest of his creativity, this autobiographical touch makes The Guide Narayan's masterpiece.

It is worthwhile to consider here the views of John Updike, who writing about Narayan's memoir opines that the autobiography of a creative writer is "superfluous" since "in rearrangement and disguise" it contains many things out of his life. The novels like Swami and Friends, The Bachelor of Arts, The English Teacher, Mr Sampath, The Guide and the stories like Breach of Promise, The White Flower, The Seventh House were written at different stages of his life and they reveal the secret of his self. Dodu of Dodu and Other Stories (1943) is none other than R.K.Laxman, Narayan's brother, the eminent cartoonist. The autobiographical element is to be marked in his literary creation, somewhere it is in abundance and at other places it is used selectively.

The memoir which is very aptly called by John Updike as "one of Narayan's most subtly and deliberately constructed books" poses before the readers many poignant scenes of his sixty-seven year old journey of life. (That was the age of Narayan when he wrote My Days.) Looking at a school photograph consisting of teachers and students of which Narayan can name only two, is one such incident. Looked as a whole, My Days because of its broad creative outlook invites the attention of discerning readers who not only rate it high but also find shreds of vintage Narayan between the covers.

The opening chapters of My Days are wholly delightful - the days spent in Madras with his maternal grandmother, Ammani. His boyhood companions - the monkey and the peacock, and his uncle (the Madras Christian College student) ever "spouting Shakespeare" were unforgettable. Narayan reminiscing of these days developed Swami and Friends. About the author's creativity Sundaram writes, 
The Christian preacher who abuses the Hindu g R.K.Narayan's My Days, published in 1974 is an autobiography with a difference. Ordinarily an autobiography is considered a piece of realistic writing true to the nuances of an individual's life. On the contrary, at times, as in the case of V.S.Naipaul, a novel is attached the tag of "non-fiction writing". However, the truth of the matter is that every fiction has an element of nonfiction just as every non-fiction has an iota of fiction in it. It is worthwhile to mention here that just after the publication of Narayan's memoir, the American University, Washington D.C. chose the same for the Englishspeaking Union's Book Abroad Literary Award.

Narayan's autobiography, like his novels, is regional in that it conveys an intimate sense of a given place - in the novels, Malgudi; in My Days, Mysore - but it is not parochial or shuttered. The life in his memoir is that of Narayan's own class, the Indian middle class, where people are not too well-off to be unperturbed about money or brutalized by the total lack of it. And above it Narayan, appears like the hero of one of his novels - sensitive, ardent, modest and wry about himself, and with a hidden resolute will. In the memoir we see, as we do in the novels, first the context of the town and the skills and problems of various kinds of work which fascinate Narayan; within this the subtler circle of the family; Narayan himself, another Narayan hero. The author as a hero can be characterised as a balanced combination of inherited tradition with a positive individual talent. Narayan's novels are easily branded as "comedies of sadness", his autobiography, in the language of Krishna Pachegaonkar, "is both suffused with a pure and unaffected melancholy and also lighted with the glint of mockery of both self and others." (p.63)

After going through a few pages, of My Days a serious reader gets the impression that in many ways it is very similar to a Narayan novel. It certainly brings home to one how much of his fiction and not only the strikingly personal The English Teacher is firmly entrenched in the details of his own experience. R.K.Narayan admits in My Days,

The English Teacher is autobiographical in content, very little part of it being fiction. The English Teacher of the novel, Krishna, is a fictional character in the fictional city of Malgudi; but he calls his wife Susila, and the child is Leela instead of Hema. The toll that typhoid took and all the desolation that followed, with a child to look after, and the psychic adjustments, are based on my wife (Rajam) should to some extent give the reader a clue that the book may not be all fiction. (pp.150-1)

The book appeared six years after the death of the author's wife, in the year 1945. Hema, the little daughter made it possible for Narayan to recover from his wife's death. She tethered him to life. Like Rajam, Susila was from Coimbatore and both of them suffered from the same royal fever, typhoid. And in a month or two they died leaving their daughter and husband all alone. Within five years of marriage Narayan lost his wife and the astrologer who had found the horoscopes of the couple not matching was proved right. This tragic experience left a void in his life and he never married to fill it. His daughter wanted his caresses and affection. This pre-occupation of looking after a motherless child gradually moulded him and made him lead a sociable life. Hema's thought and responsibility never allowed Narayan to escape. The result is The English Teacher and the gift of voluminous other works of the author for the society.

Narayan's protagonist, Krishnan followed the author's footsteps in the novel The English Teacher. Even though he went for an arranged marriage and had to live a few years without his wife and daughter, his love for his wife is no less than Narayan. Like Narayan, his hero earned his livelihood from English literature, as he was a professor in English at Albert Mission College. He had to deal with Shakespeare, Carlyle, Milton and so on. As a professional, Krishnan was an able teacher and was loved by his students. The farewell speech of $\mathrm{Mr}$ Brown, the principal of Albert Mission College is an ample testimony to this. Krishnan was regular and punctual in his work even after his wife's death. Being an affectionate and responsible husband and father, he shared his time with both of them. He prepared the sick room, maintained the chart of Susila's temperature, pampered her to take medicine, and spent time with her. On the other hand, when he was freed from these responsibilities, he was back on his father's role. Read stories to his daughter, Leela; played with her; took her for outing. He also looked after her cleanliness, food, etc. By now Krishnan had started playing the role of both father and mother to his child. Same must be the situation for Narayan himself. And very soon he had to take care of all the requirements of Leela, as Susila collapsed one fine evening. This terrible experience left its indelible mark on Krishnan and like Narayan he decided not to marry again. Susila like Rajam died out of typhoid after she had spent a holiday at her parents' place at Coimbatore. After his wife's death Krishnan said, "I'm an imbecile, incapable of doing anything or answering any questions. I'm incapable of doing anything except what our priest orders me to do." (p.96) And the same man responded sensibly and intelligently to the problems that came on his way, only for his child. One finds the intensity of pain and agony in the writings of Narayan especially, in handling this episode. And can also visualise Rajam in place of Susila through the thoughts of the author. Like Hema, Leela also made his father come out of his mother's thoughts, and lead his life. Krishnan's life like Narayan's after his wife's tragic fate revolved around Leela.

The conversation between the father and child on trivial issues, the father's concern, and their affection for each other made the readers think it to be Narayan's real life experience. In her child-like 
innocence, Leela made her father answer her childish questions. Making Krishnan busy with her work forces the readers visualise Narayan in place of Krishnan. Narayan must have undergone similar pain and faced such situations in his real life. For instance, once Leela insisted upon being read the stories by his father in the odd hour. He makes plea of cleaning oneself before touching books, as Goddess Saraswathi, the Goddess of learning would be unhappy with them. To which she enquires, "Why should I be learned?" And her father adds, "You can read a lot of stories yourself without my help. Oh! What will you do then?" (p.103) The intensity of feeling, the accuracy of thought, compelled his critics to find an autobiographical element in it. Another incidence worth mentioning here is the lawyer episode. In Narayan's memoir it is mentioned that a lawyer in his street once peeped over his gate and said,

"Sorry, mister. I have also suffered the same fate. You must and will get over it." He had lost four wives in his matrimonial career and remarried each time, but at the moment was again a widower. (pp.153-4)

And in The English Teacher Narayan has used a perfect stranger, old woman, who by seeing the motherless child Leela peeps from the bus and comments,

A man must marry within fifteen days of losing his wife. Otherwise he will be ruined. I was the fourth wife to my husband and he always married within three weeks. All the fourteen children are happy. What is wrong? (p.99)

The original thought of the lawyer, the neighbour of the author is presented through the old lady in The English Teacher. Narayan wanted to reply to the lawyer in his real life and could not. So also did his character, Krishnan in the novel.

The protagonist, by profession an English teacher had the creative skill of writing poems and even wished to get them published. Narayan's trait of writing is also shared by Krishnan in The English Teacher. Like the author he also thought of writing a poem on the situation, of his wife, when the mercury in the thermometer was static at the highest level and was not falling. Kishnan sitting near his sick wife and seeing her talking in sleep, wrote,

The Great Kailas is one Mound of Ice

Where Shiva and Parvathi sport,

But so far it is not the fever which cools,

But Ice that melts. (p.86)

Krishnan follows the foot prints of his author to get rid of this dilemma. Narayan, as he did in his real life, makes his hero take the help of art by complete submission to it in this most difficult situation. And through the poem Krishnan could give vent to his sentiment and make himself prepared for the next tough situation. His agony and worry is distinctly visible in the poem, his love and concern too. Unlike Narayan he could not write a novel but has written a poem for her wife with utmost candidness.

The second part of The English Teacher also consists of autobiographical touch. Ragunath Rao (in Narayan's personal life) and the farmer (in his protagonist's life) helped in psychic communion with their respective wife. And the author's experience at Ragunath's place is being shared by Krishnan in the novel. The regular visit on Wednesdays, sitting fingers crossed to get some message from his wife, preserving the filled scripts of the psychic communion for life long and even self attempt of psychic communion are Narayan's life experience, represented through his hero.

Another novel of R.K.Narayan, The Bachelor of Arts (166 page creative production) is divided into four parts - education, infatuation, realisation and conjugal prosperity of Chandran. The protagonist Narayan, another Narayan hero, can co-relate his experiences with Chandran. The presence of autobiographical element in his writings makes him a hero in his memoir My Days. This is not the case with Narayan alone. The other novelists like Defoe, Richardson and James Joyce are in the game; they try to keep themselves away from their creativity but cannot betray their opinion. The choice of characters, situations, the thoughts and feelings are of the author.

There is more of Narayan's personal influence in the second novel The Bachelor of Arts than in any other except The English Teacher, which happens to be the fourth in the series of creation. Chandran's experiences in Albert college; trying to stick to the exam preparation time-table, being part of non-academic matters, passing comments on teachers and principal at his naughty mood, playing pranks with friends, attending classes sincerely and obeying his teachers; seem to be based on the author's life experience in Maharaja's college, Mysore. The vivid description of these scenes forces his readers to deduce the conclusion that it is only Chandran who is playing the role of real Narayan in the novel. Ramu, his "inseparable friend", who keeps his company during and long after the college hours, smokes and watches late night movies is Ramachandra Rao, who finds a mention in his memoir My Days and jointly studied in the days of his final year examination. Perhaps, like the hero he also misses him long after their academic career. Chandran and Ramu, friend and neighbour of the protagonist started the day with their journey to the college, attended the lectures, returned home only to freshen up for the night show cinema. Narayan writes, "Chandran was none of your 
business-like automatons who go to a cinema, sit there, and return home. It was an aesthetic experience to be approached with due preparation."(p.13) Both accompanied each other in chewing betel leaves and nut; smoking cigarette all the time they were together and icing it with the midnight coffee. Chandran adds, "Ramu's company was most important to him. It was his presence that gave a sense of completion to things."(p.13) And same was Ramachandra for Narayan.

Chandran of The Bachelor of Arts falling headlong in love with Malathi, who came to the river bank of Sarayu with her younger sister almost daily, reminds one of Narayan of 1933. It reminds of similar incidents Narayan went through when he had gone to Coimbatore escorting his elder sister and lived in her place. Both the love stories flourished near the water source, one playing with her sister near the river bank and other drawing water from the tap. Like Chandran, his author says in the memoir, "One day, I saw a girl drawing water from the street-tap and immediately fell in love with her."'(p.117) And in the novel explaining both the lovers' condition he writes, "No one can explain the attraction between two human beings. It happens."(p.54) The horoscopes in both the lovers' life i.e., Chandran and Narayan created difficulties in the union with their beloveds. Ganapathi Sastrigal (in the novel), the match-maker's idea on horoscope "to know whether two persons brought together will have health, happiness, harmony, and long life" (p.78) was also the thought of both the parents (bride and groom) within and outside the novel. Narayan succeeded in making the stars favourable (for the time being) and could convince the girl's father to agree to the marriage. Chandran and his father did their best with the astrologer, Srouthigal to make the two horoscopes "well matched". But D.W.Krishna Iyer, father of the girl, who had little knowledge of astrology had his doubts. He says,

Since I have great faith in horoscopy, and since I have known from experience that the marriage of couples ill-matched in the stars often leads to misfortune and even tragedy, I have to seek a bridegroom elsewhere.(p.86)

These words made Chandran, writes Sundaram, fall into "the deepest depths of despair". This incident led Chandran to leave Malgudi and seek solace in the ochre robes. But in case of Narayan the love-story ended with the bondage of wed-lock.

Another character of The Bachelor of Arts, Kailas the eccentric hotel mate of Chandran at Madras, who considered beer as lacking in alcoholic content, offered it to Chandran, the non-alcohol consumer. He could even steadily drink gin after whisky and whisky followed by gin from five to eight-thirty in the evening. The author imagining one of his younger uncle's drunken bouts mentioned in his autobiography that Kailas is modelled after him, as he was equally fond of bottles. Then he became a fake tiger who snarled and stalked in the hotel corridor behind every passerby until sleep took over. Kailas raised a similar kind of situation for the protagonist in the bar, on the street and near his temporary destination. Even Seenu, Chandran's younger brother is not a fictitious character rather one of Narayan's brother, who was of the same name and characteristics. In My Days Narayan writes, "Seenu, one year junior in our class, always obliging, would willingly undertake ....."(p.79) any responsibility assigned to him.

While discussing Narayan's life, none can forget Narayan's creative career, which is represented by Mohan, friend of Chandran in The Bachelor of Arts. Mohan, the newspaper reporter of The Daily Messenger in the novel, and the author, were into the same profession for the Justice and Indian Thought of Madras. Both the reporters dealt with cases in the court, traffic accidents, suicides and murders, and were busy in posting them. Sundaram writes,

When Chandran gets the agency for The Daily Messenger and plans his four-pronged attack on the public to push up its sales -- Information, Illumination; Appeal and Force -- it is difficult not to conclude that some such process must have been set in motion by Narayan himself when he embarked on his journalistic venture Indian Thought.(p.27)

One such occurrence is when Chandran returns from his exile and looks for his "inseparable friend" Ramu, but never received any satisfactory answer. Then he reminiscences the moment they shared together and comments how they studied for four years, developed compatibility, made friends, arranged functions. All these are saved in a group photograph, which after a few years was sent to the store room. In a passage in My Days Narayan has dealt with a similar theme i.e., school photograph. Looking at a school photograph consisting of teachers and students, Narayan can name only two. For eight long years he like his hero reminiscences, "reading, playing and suffering our teachers together...... where are my fellow Olympians at this moment?'(p.46)

In a way Narayan's first novel, Swami and Friends which deals with the hero's growth into maturity through a number of adolescent audience, is an autobiographical novel. A section of My Days is strongly reminiscent of these events of the Narayan novel. In those days a child being brought up elsewhere than in the care of one's parents was something common and Narayan too was sent to his granny in Madras so that the young mother can care for the other children. The boy Narayan's liking for domestic animals: the peacock, the monkey, the green parrot and the little hairy puppy is something which can hardly be ignored. Walking in the streets of Madras hand in hand with his uncle, he received enormous materials which were nutrition for his 
imagination and education for his feelings. Both in My Days and Swami and Friends Narayan's life in Madras and his nostalgia for the school days are all too common. Going through the highly readable autobiography of Mr Narayan one gets a scent of his attention, his allergy for abstract arithmetic, his irritability with intrusive adults and his desperate attempt to manage the unyielding angularities of the adult world. One more thing that strikes a discerning reader is Narayan's portrayal of his father as a stern headmaster, not very different from the headmaster of the Swami and Friends.

In Mr Sampath: The Painter of Malgudi one can observe the similarity of Srinivas' professional career with Narayan. As we know Narayan himself edited a journal like Srinivas. Even Narayan's Indian Thought was less successful and more baffling in its purpose than The Banner of Mr.Sampath. Narayan writes in My Days, 'Mr. Sampath, who was my printer (and who became a character in one novel and two film stories), had said bluntly, 'I'll do the printing side but you must provide the paper....'(p.173) And Sampath in the novel is modelled on real life one, who had versatile talents. Beside printing, both had knack for theatre. The author's experience with the zany Indian film industry when they introduced all sorts of lunatic energies on producing a commercial version of his favourite novel The Guide, is not different from that of Srinivas (The Burning of Kama). The novelist mentions in his memoir that the multi-faceted Sampath of real life, i.e. Narayan, also became a busy film personality without neglecting his press work. Srinivas represents the author's adventures in running Indian Thought and Sampath follows his example with his experience of the film industry. This has much similarity with V.S.Naipaul who is believed to use autobiographical elements in his works.

There is also reference to Narayan's life falling "firmly into a professional pattern: books, agents, contracts........"(p.209) and it has found its place in another novel of his i.e., The Guide. Raju, the protagonist had to pass through similar situations like his author while he was a career-guide to Rosie. Narayan's numerous letters to known and unknown people alike, his travels for days together, and above it his enjoyment of the situation rather than complaints also has a mention in this highly rated novel. In 1956 Mysore faced a severe drought and it dried up all the rivers and tanks; revealed an ancient submerged temple, dehydrated crocodiles. Narayan writes in his autobiography, "At this time I had been thinking of a subject for a novel: a novel about someone suffering enforced sainthood. A recent situation in Mysore offered a setting for such a story."(p.188) And this became the theme for the novel. Apart from rest of his creativity, this autobiographical touch makes The Guide Narayan's masterpiece.

It is worthwhile to consider here the views of John Updike, who writing about Narayan's memoir opines that the autobiography of a creative writer is "superfluous" since "in rearrangement and disguise" it contains many things out of his life. The novels like Swami and Friends, The Bachelor of Arts, The English Teacher, Mr Sampath, The Guide and the stories like Breach of Promise, The White Flower, The Seventh House were written at different stages of his life and they reveal the secret of his self. Dodu of Dodu and Other Stories (1943) is none other than R.K.Laxman, Narayan's brother, the eminent cartoonist. The autobiographical element is to be marked in his literary creation, somewhere it is in abundance and at other places it is used selectively.

The memoir which is very aptly called by John Updike as "one of Narayan's most subtly and deliberately constructed books" poses before the readers many poignant scenes of his sixty-seven year old journey of life. (That was the age of Narayan when he wrote My Days.) Looking at a school photograph consisting of teachers and students of which Narayan can name only two, is one such incident. Looked as a whole, My Days because of its broad creative outlook invites the attention of discerning readers who not only rate it high but also find shreds of vintage Narayan between the covers.

The opening chapters of My Days are wholly delightful - the days spent in Madras with his maternal grandmother, Ammani. His boyhood companions - the monkey and the peacock, and his uncle (the Madras Christian College student) ever "spouting Shakespeare" were unforgettable. Narayan reminiscing of these days developed Swami and Friends. About the author's creativity Sundaram writes,

The Christian preacher who abuses the Hindu gods and is "pelted with mud and stones" as well as the Mission School teacher with his tirades against "idolaters" will in time be transported from real life to Narayan's novels, Mr Sampath and Swami and Friends respectively. Kunjappa "hiding himself behind dirty clothes heaped on a stand" will provide the theme for Narayan's story The Performing Child. (p.3)

The author's falling in love and taking every possible step to get accomplished is the passing phase of Chandran in The Bachelor of Arts. The pain and agony due to his wife's death can be experienced by Krishnan, the protagonist of The English Teacher, who played Narayan in the novel. The later part of the memoir deals with his journalistic career and became the theme for Mr Sampath and also The Bachelor of Arts. Narayan's failure and success as an editor of the journal called Indian Thought are also echoed in the novel Mr Sampath where Srinivas just like the author shares these experiences. Narayan's life, as Graham Greene foretold, gradually fell into the pattern of that of the professional writer, and as the years passed, of the successful professional writer. Narayan, however, developed a devoted readership, stretching from New York to Moscow. Nothing succeeds like success. He is duly admitted to the elite community of the fiction writers, and today his reputation stands far above the common run, unrivalled and unstilted. Narayan, in the later half of his 
autobiography, is associated with books, agents, contacts and plenty of letter-writing. Of course, travel over and over again is the food of thought for The Guide. As an autobiography My Days is both revealing and has a touch of intimacy about it. With due care, it not only portrays the vicissitudes of Narayan's personal life but also his predilections both as an individual and writer. As an autobiography it reflects the activities of Narayan's literary characters to an extent which even a John Updike did not ordinarily visualise.

\section{Works Cited}

[1]. Narayan R.K. My Days Autobiography. Chennai: Indian Thought Publication, 2010. Print.

[2]. Narayan R.K. Swami and Friends. Mysore: Indian Thought Publication, 1942. Print.

[3]. Narayan, R.K. The Guide, Madras: Indian Thought Publication. 2002. Print.

[4]. Narayan, R.K. The Writerly Life. Ed. S.Krishna. New Delhi: Viking - Penguin Books, 2001.

[5]. Narayan, R.K. Mr Sampath, Chennai: Indian Thought Publication, 2009. Print.

[6]. Narayan, R.K. The English Teacher. Chennai: Indian Thought Publication, 2011. Print.

[7]. Narayan, R.K. The Bachelor of Arts. Chennai: Indian Thought Publication, 2011. Print.

[8]. Narayan, R.K. My Dateless Diary: An American Journey. New Delhi: Penguin Books, 1988. Print.

[9]. Pachegaonkar Krishna, R.K.Narayan's Autobiography: “My Days”, Triveni, Vol. 55, No.4, 1987.

[10]. Sundaram P.S. R.K.Narayan As A Novelist, B.R. Publishing Corporation, New Delhi, 1988.

[11]. Walsh Willam. R.K.Narayan: A Critical Apprection, Chicago:The University of Chicago Press, 1982. 